\title{
Effectiveness and Tolerance of Tenofovir Disoproxil Fumarate in Sub-Saharan Viral B Cirrhotic Patients
}

\author{
Doumbia K. Wife Samaké*, Sow H. Wife Coulibaly, M. Y. Dicko, A. M. Diallo, \\ Sanogo S. D. Wife Sidibe, A. Kondé, M. C. Tounkara, D. Sangare, A. Konaté, \\ M. T. Diarra, M. Y. Maïga \\ Hepato-Gastroenterology Department, CHU Gabriel, Bamako, Mali \\ Email: *samakekatia@yahoo.fr
}

How to cite this paper: Samaké, D.K.W., Coulibaly, S.H.W., Dicko, M.Y., Diallo, A.M., Sidibe, S.S.D.W., Kondé, A., Tounkara, M.C., Sangare, D., Konaté, A., Diarra, M.T. and Maïga, M.Y. (2019) Effectiveness and Tolerance of Tenofovir Disoproxil Fumarate in Sub-Saharan Viral B Cirrhotic Patients. Open Journal of Gastroenterology, 9, 43-47.

https://doi.org/10.4236/ojgas.2019.92007

Received: January 11, 2019

Accepted: February 25, 2019

Published: February 28, 2019

Copyright $\odot 2019$ by author(s) and Scientific Research Publishing Inc. This work is licensed under the Creative Commons Attribution International License (CC BY 4.0).

http://creativecommons.org/licenses/by/4.0/

\section{(c) (i) Open Access}

\begin{abstract}
Tenofovir reduces viral load during viral cirrhosis B and improves prognosis. The aim of this study was to evaluate the effectiveness and safety of Tenofovir during the treatment of viral B cirrhosis. The study was retrospective and prospective on patients with viral B cirrhosis treated with Tenofovir in the Hepato-Gastroenterology Department of University Hospital Gabriel Touré in Bamako (Mali) and evaluated between three and six months after the start of treatment. We included 89 patients. The mean age was $44.5 \pm 16$ years with extremes of 18 and 90 years. The sex ratio was 1.2. At inclusion all patients had a detectable viral load with an average of $2651.96 \pm 1495.85 \mathrm{IU} / \mathrm{ml}$. Follow-up viral load was undetectable in $84.3 \%$ with patients between 3 and 6 months of treatment. The average detectable viral load was only $27.04 \pm 21.05$ $\mathrm{IU} / \mathrm{ml}$. There was also an improvement in hepatocellular function and few side effects. Conclusion: This study shows the interest of Tenofovir in the treatment of viral cirrhosis B with very few adverse effects.
\end{abstract}

\section{Keywords}

Cirrhosis, Tenofovir, HBV

\section{Introduction}

Cirrhosis is serious by its frequent complications [1] [2]. The main causes of this disease are hepatitis B virus (HBV), hepatitis $\mathrm{C}$ virus (HCV) and alcohol consumption [3] [4] [5] [6].

In tropical area hepatitis B virus is the most frequent cause of cirrhosis [3] [4] 


\section{[5] [6] [7] [8].}

Current treatments by nucleic analogue and interferon can stop virus replication and thus stabilization or even improvement of hepatic disease [9]. Tenofovir Disoproxil Fumarate (TDF) effectiveness has been proven with the advantage of having a high genetic barrier against the virus [9] [10]. However, the major risk of this drug is its renal toxicity and bone defect [11].

In Mali, the prevalence of HBs antigen in the general population ranges from $13.9 \%$ to $15.5 \%$ [12] [13] and this viral marker was found in $55 \%$ to $71 \%$ of cirrhosis and in $55 \%$ to $62.2 \%$ of hepatocellular carcinoma [3] [14] [15]. TDF is more and more accessible in the treatment of HBV infection. The risk of this treatment has not been evaluated in our context. We initiated this study with the aim to evaluate the efficiency and safety of TDF in viral B cirrhotic patients.

\section{Patients and Methods}

The study was retrospective from April 2014 to April 2015 and prospective from May 2015 to October 2016 and took place in the service of Hepato-gastroenterology of CHU Gabriel Touré in Bamako, Mali.

The study included HBV cirrhosis patients treated with TDF. The patients had HBV viral load assay at the start and between 3 and 6 months of the treatment. For the retrospective period the data were collected from the service records. During the prospective period the data were recorded in real time. The study parameters collected were gender, age, causes of consultation, clinical examination data, HBV viral load, adverse effects of TDF, the course of the disease.

All the patients were informed about the course of the study and gave their approval.

Data analysis was done on Epi Info statistical software version 6.04. The chi ${ }^{2}$ statistical test was used to analyze our results with a significance level for $\mathrm{P}<$ 0.05 .

\section{Results}

At the end of the study, 89 patients were collected. The sex ratio was 1.2 (66 men versus 23 women). The average age of the patients was $44.5 \pm 16$ years with extremes of 18 and 90 years. The 25 - 34 age group was more represented. Ascites and jaundice were the main causes of consultation (Table 1). At inclusion, ascites and hepatomegaly were the most observed clinical signs (Table 2). The HBV viral load, detectable in the all patients, was greater than $2000 \mathrm{IU} / \mathrm{ml}$ in $49.4 \%$ of patients with an average of $2651.96 \pm 1495.85 \mathrm{IU} / \mathrm{ml}$. In $65.2 \%$ of cases the patients had decompensated cirrhosis. The TDF treatment improved significantly hepatocellular function (Table 3). After three months of treatment the viral load became undetectable in $84.3 \%$ of patients and the average detectable viral load was only $27.04 \pm 21.05 \mathrm{IU} / \mathrm{ml}$. Nephropathy was observed in 8 patients (Table 4). The global mortality was $7.9 \%$ (7 patients including 3 with nephropathy). 
Table 1. Causes of consultation.

\begin{tabular}{ccc}
\hline Causes for consultation & Number & $\%$ \\
\hline Ascites & 17 & 19.1 \\
Jaundice & 16 & 18 \\
Ascites + IMO & 12 & 13.5 \\
Hematemesis & 11 & 12.3 \\
Abdominal pain & 09 & 10.1 \\
Emaciation & 07 & 7.9 \\
Hepatomegaly & 06 & 6.7 \\
Consciousness disorder & 04 & 4.5 \\
bloating & 04 & 4.5 \\
Hematemesis + hematochesis & 03 & 3.4 \\
Total & 89 & 100 \\
\hline
\end{tabular}

Table 2. Clinic signs.

\begin{tabular}{ccc}
\hline Clinical signs & Number & $\%$ \\
\hline ascites & 64 & 71.9 \\
Hepatomegaly & 49 & 55.1 \\
Jaundice & 45 & 50.6 \\
Splenomegaly & 27 & 30.3 \\
CVC & 25 & 28.31 \\
Neurogical disorders & 15 & 16.9 \\
\hline
\end{tabular}

Table 3. Cirrhotic biological corse during the treatement.

\begin{tabular}{cccc}
\hline Biology & $\begin{array}{c}\text { At inclusion } \\
\mathbf{n}(\%)\end{array}$ & $\begin{array}{c}\mathbf{3 - 6} \text { months later } \\
\mathbf{n}(\%)\end{array}$ & $\mathbf{p}$ \\
\hline Protrombine rate $(\mathrm{n}=89)<50$ & $31(34.8)$ & $19(21.3)$ & $\mathbf{0 . 0 4 5}$ \\
Bilirubin $(\mathrm{n}=89)>35$ & $42(47.2)$ & $36(40.4)$ & 0.364 \\
Albumin $(\mathrm{n}=89)<35$ & $37(41.6)$ & $18(20.2)$ & $\mathbf{0 . 0 0 2}$ \\
Platelet $(\mathrm{n}=89)<150.10^{3}$ & $57(64)$ & $36(40.4)$ & $\mathbf{0 . 0 0 1}$ \\
\hline
\end{tabular}

Table 4. Adverse effects of treatement.

\begin{tabular}{cccc}
\hline $\begin{array}{c}\text { Biological } \\
\text { assessement }\end{array}$ & $\begin{array}{c}\text { Month 1 } \\
\mathbf{n}(\%)\end{array}$ & $\begin{array}{c}\text { Month 2 } \\
\mathbf{n}(\%)\end{array}$ & $\begin{array}{c}\text { Month 3 - Month 6 } \\
\mathrm{n}(\%)\end{array}$ \\
\hline Creatininemia $>120$ & $4(4.5)$ & $6(6.7)$ & $6(6.7)$ \\
$(\mathrm{n}=89)<120$ & $85(95.5)$ & $83(93.3)$ & $83(93.3)$ \\
Glycosuria $(\mathrm{n}=89)$ & No & No & No \\
Phosphoremia $(\mathrm{n}=89)$ & No & No & $1(1.1)$ \\
Urinate protein $(\mathrm{n}=89)$ & No & No & $2(2.2)$ \\
\hline
\end{tabular}




\section{Discussion}

At the end of this study, $89 \mathrm{HBV}$ cirrhotic patients were included. This sample was limited by the difficulties to perform in some patients biological tests including viral load for financial reasons. The sex ratio in our study was $1.2 \mathrm{in} \mathrm{fa-}$ vor of men. This frequency was lower than that found by Doumbia et al. which was 2.28 [16]. On the other hand, Diarra reported 1.09 in favor of women [17]. This male predominance could be explained by the frequency of the chronic carriage of HBV in men, causing the most cirrhosis in our context [16].

The average age of the patients was $44.5 \pm 16$ years. This frequency is similar to those reported by Maïga et al. [18], Diarra et al. [2], Diarra [17] and Doumbia et al. [16] which were respectively 43.25 years, 41.5 years, 42 years and 43.8 years. Ascites and hepatomegaly were the most common clinical signs with 71.55 and $55.1 \%$ respectively; Doumbia et al. [18] found jaundice (58.1\%), hepatomegaly (36.2\%) as the main signs. For Pariente [19] ascites is a telltale sign of cirrhosis.

A viral load greater than $2000 \mathrm{IU} / \mathrm{ml}$ in almost the half patients attests the frequency of virus replication and therefore also cirrhosis activity. Hepatocellular function was also advanced in $65.2 \%$ of patients. In the same context Diarra et al. [17] reported that $90.2 \%$ of patients were at B or C stage of the Child-Pugh score.

The treatment by TDF improved significantly hepatocellular function $(\mathrm{P}=$ 0.045 to 0.002 ). This result is certainly attributed to the control of viral replication because the viral load became undetectable in $84.3 \%$ of patients. This non detectability occurred between 3 - 6 months of treatment with an average of detectable viral loads of only $27.04 \pm 21.05 \mathrm{IU} / \mathrm{ml}$. Guindo [20], in a VHB hepatitis treated by the same drug, reported a non-detectable viral load in $32.14 \%$ of patients within.

During treatment, renal injury was observed in seven patients. Guindo [20] found no adverse effect in the same time limit. In one study [11], it was reported a hypercreatininemia, hyperphosphatemia after 48 first weeks of treatment.

The mortality was $7.9 \%$. On the seven deaths, three had renal involvement during treatment. But the benefit of this treatment greater than the adverse effects and justifies its use during HBV infection at any stage.

\section{Conclusion}

The interest of Tenofovir in the treatment of viral cirrhosis B is well established. A national policy must work for the availability of this drug. Emphasis should also be placed on birth vaccination against HBV.

\section{Conflicts of Interest}

The authors declare no conflicts of interest regarding the publication of this paper.

\section{References}

[1] Balian, A. (2005) Cirrhosis and Its Complications, Collection Conduite. Doin XVI, DOIN, Paris, $171 \mathrm{p}$. 
[2] Diarra, M., Konaté, A., Soukho, A., Epouse, K., et al. (2010) Corse of Cirrhotique Disease in Hepato-Gasroenterology Service in Mali. Mali Medical, 25, 42-46.

[3] Dembélé, M., Maïga, I., Minta, D., et al. (2004) HBs Ag and HCV Antibodies in Chronic Liverdiseases in Hospital Services in Bamako, Mali. Bulletin de la Société de Pathologie Exotique, 97, 161-164.

[4] Perret, J.L., Kombila, M.J.B., Delpaporte, E., et al. (2002) HBs Ag and HCV Antibodies in Chronic Complicated Liver Diseases in Gabon. Gastroentérologie Clinique et Biologique, 26, 131-135.

[5] Touré, E. (2008) Aspects Epidemiological, Etiological, Clinical and Therapeutic Aspect of Cirrhosis in National Hospital of Niamey. These Medecine, Bamako.

[6] Saley, M. (2004) Prevalence of Chronic Liverdiseases in National Hospital of Niamey: Epidémiological, Clinical, Paraclinical and Etiologicalaspects. These Medecine, Niamey.

[7] Konaté, A., Diarra, M., Minta, D., et al. (2005) HCV Infection in Liver Chronicdiseases in Mali. Mali Medical, 20, 11-13.

[8] Ott, J.J., Stevens, G.A., Groeger, J., et al. (2012) Global Epidemiology of Hepatitis B Virus Infection: New Estimates of Age-Specific HBsAg Seroprevalence and Endemicity. Vaccine, 30, 2212-2219. https://doi.org/10.1016/j.vaccine.2011.12.116

[9] Zoulim, F. and Locarnini, S. (2009) Hepatitis B Virus Resistance to Nucleos(t)ide Analogues. Gastroenterology, 137, 1593-1608.

https://doi.org/10.1053/j.gastro.2009.08.063

[10] Van Bommel, F., Wunsche, T., Mauss, S., et al. (2004) Comparison of Adefovir and Tenofovir in the Treatment of Lamivudine-Resistant Hepatitis B Virus Infection. Hepatology, 40, 1421-1425. https://doi.org/10.1002/hep.20464

[11] http://www.hepfi.org/

[12] Bougoudogo, F., Diarra, S., Traoré, S., et al. (2001) Prevalence of HBV Serological Markers of HBV in Mali. http://www.sante.gov.ml/

[13] Dembélé, R. (2011) HBV Epidémiological and Serological Profile in Urba Area in Bamako. These Medecine, Bamako.

[14] Maïga, M.Y., Dembélé, M., Diallo, F., et al. (2002) Uper Digestive Endoscopy Valuein Cirrhhosis. Acta Endoscopica, 32, 211-218.

[15] Diarra, M., Konaté, A., Dembélé, M., et al. (2006) Hepatocellularcarcinoma: Epidemiological and Prognosis Aspects. Medecine Afrique Noire, 53, 23-28.

[16] Doumbia épouse Samaké, K., Diarra, M., Konaté, A., et al. (2012) Ascites, Worsen Complication in Cirrhotic Patient in Tropical Area in Mali. Medecine Afrique Noire, 59, 274-278.

[17] Diarra, A.B. (2009) Ascites Liquid Infection in Cirrhotic Patient in the Service of Hepato-Gastroloenterology of CHU GT. These Medecine, Bamako, No. 210.

[18] Maïga, M.Y., Traoré, H.A., Dembélé, M., et al. (1996) Ascites Liquid Infection in Internal Service of Medicine at the National Hospital of Pont G. Médecine et Chirurgie Digestives, 25, 219-222.

[19] Pariente, A. (2006) Ascites Decompensation. Gastroentérologie Clinique et Biologique, 30, 870-874. https://doi.org/10.1016/S0399-8320(06)73334-6

[20] Guindo (2016) Effectiveness and Tolerancy of Ténofovir Disoproxil Fumarate in the Treatment of HBV Monoinfection at Tree-Six Months. Memory Medecine, Bamako. 